\title{
IMPROVING THE EFFICIENCY OF THE STABILIZATION COLUMNS IN OIL AND GAS PROCESSING
}

\author{
DENIS ERMOLIN ${ }^{1}$, ELENA MAGARIL ${ }^{2} \&$ ROMEN MAGARIL ${ }^{3}$ \\ ${ }^{1}$ Sosnogorsk Gas Processing Plant LLC Gazprom Recycling, Sosnogorsk, Russian Federation \\ ${ }^{2}$ Department of Environmental Economics, Ural Federal University, Russian Federation \\ ${ }^{3}$ Department of Oil and Gas Processing Technology, Tyumen Industrial University, Russian Federation
}

\begin{abstract}
Rectification process is widely used in oil and gas processing and petrochemistry. The composition of the bottom product of the rectification column usually differs from the equilibrium composition due to significantly higher content of light components or fractions. This stipulates a necessity to include into the technological schemes of several oil refining processes a stabilization unit that are meant to ensure separation of gases and liquid products. A highly relevant task is to explore new possibilities for improving the stabilization process. The aim of the present work was to improve the stabilization process by changing the operating pressure. It was found that increasing the pressure in the stabilization column enhanced the sharpness of separation of butanes from pentanes, which resulted in improving the quality of the products. The experimental-industrial runs confirmed the possibility of increasing the efficiency of stabilization columns in various processes by increasing the pressure within acceptable limits.
\end{abstract}

Keywords: rectification process, sharpness of separation, stabilization column, pressure.

\section{INTRODUCTION}

The process of rectification has been widely used in petroleum refining and petrochemistry for quite a long time and considered by many researchers [1]-[4]. By means of rectification during the oil and gas primary processing the straight-run fractions are obtained for their subsequent use as a feedstock in the processes of production of motor fuels or in the petrochemical industry [1]. It is also important to use rectification for the stabilization of final products [5].

Due to high energy consumption in the rectification process the problems of energy efficiency of plants have attracted particular attention [6], [7]. There is an eventual necessity for improving the process technology to increase the rectification efficiency.

The choice of pressure in the rectification column is usually associated with a required temperature regime [1], [8], [9]. The studies available on the effect of pressure on the efficiency of rectification columns have often been controversial [7], [10], [11]. Previously, it was theoretically shown that the sharpness of fractionation of rectification columns in the process of operation can be substantially improved by increasing their operating pressure [12], [13]. On this basis, recommendations on ensuring the sharpness of fractionation in the deethanization columns by increasing the pressure were developed [14]. It is of considerable interest to investigate the possibility of increasing the sharpness of fractionation by changing the pressure in other rectification columns, including stabilization columns which enable separation of gases and liquid products.

\section{SCOPE FOR INCREASING THE EFFICIENCY OF STABILIZATION COLUMNS BY CHANGING THE OPERATING PRESSURE}

Stabilization columns are included into the technological schemes of a number of oil refining processes to improve the quality of products. The process of stabilization is the separation in stripping columns of gases, including butanes, and liquid products, starting with pentanes. 
The process is used for the separation of gasoline from associated petroleum gas and production of gasoline in various refining processes, as well as for processing deethanized condensate.

The rate of the gas-liquid interaction is determined by the diffusion of the gas into the liquid. When increasing the pressure, the contact time between the gas and liquid phases increases and the surface tension at the gas-liquid interface decreases due to an increase in the gas density. This leads to an increase in the dispersion of gases bubbling through the liquid and effect of pressure is supposed to accelerate the diffusion interfacial mass transfer. The rate of diffusion $\mathrm{G}$ (the amount of substance diffused per unit time, $\mathrm{kg} / \mathrm{s}$ ), according to the Fick's first law, is determined by the eqn (1):

$$
G=K \cdot \frac{D \cdot F}{\delta} \cdot(\pi \cdot y-P \cdot x)
$$

where $K$ is a coefficient, $\mathrm{s}^{2} / \mathrm{cm}^{2} ; D$ is the coefficient of diffusion of the gas molecules into the liquid, $\mathrm{cm}^{2} / \mathrm{s} ; F$ is the gas-liquid contact area, $\mathrm{cm}^{2} ; \delta$ in the thickness of the boundary film, $\mathrm{cm} ; \pi$ is the overall gas pressure, $\mathrm{Pa} ; P$ is the partial pressure of a diffusing component in the liquid, $\mathrm{Pa} ; y$ is the mole fraction of the component in the gas vapor; $x$ is the mole fraction of the component in the liquid.

According to the eqn (1) an increase in the overall gas pressure will lead to an increase in the diffusion rate.

\section{INVESTIGATION OF THE EFFECT OF PRESSURE ON THE EFFICIENCY OF STABILIZATION COLUMNS}

In order to investigate the effect of changing the pressure in the rectification system on the efficiency of the stabilization column, the experimental-industrial run was carried out on the basis of the installation for the low-temperature condensation at the Sosnogorsk gas processing plant, LLC "Gazprom pererabotka" (Sosnogorsk GPP), with a constant capacity of $280,000 \mathrm{~m}^{3} / \mathrm{h}$ of the associated petroleum gas.

Under the experimental-industrial run of the column equipment the operating pressure range for the debutanizer was changed from 0.9 to $1.2 \mathrm{MPa}$. The upper limit of the parameter considered was limited by the maximum operating (routine) value of the installation pressure. The loading of the butane column with the column feedstock was $14 \mathrm{t} / \mathrm{h}$.

Results of the study of the effect of pressure on the operation of the butane column are presented in Table 1 and Fig. 1.

The obtained results of the experimental-industrial run of the butane column of the Sosnogorsk GPP revealed that increasing the operating pressure in the debutanizer during the APG processing resulted in the significant improvement of the sharpness of separation of the target products.

Table 2 presents the information on the design and average statistical data on the operating mode for the stabilization columns of straight-run gasolines of several oil refineries. According to the data presented in Table 2 all the stabilization columns provided the output of the conditioned fraction IBP $-180^{\circ} \mathrm{C}$.

In each case, there was a margin of quality regarding the requirements for butane content.

The content of pentane in the column top product was in a range of $2.17-2.38 \mathrm{wt} . \%$. The stabilization columns under consideration had comparable technological modes of operation.

The temperature regime and reflux-to-product ratio corresponded to the optimum values allowed by the technological regulations. For each plant, there was a significant scope to increase the operating pressure in the column to the values allowed by the technological 
Table 1: Experimental data on the operation efficiency of the debutanizer 106-C3 of the Sosnogorsk GPP.

\begin{tabular}{|l|c|c|c|c|c|}
\hline \multirow{2}{*}{ Parameter of the mode } & \multicolumn{6}{|c|}{ Value of parameters at the given pressure, MPa } \\
\cline { 2 - 6 } & 0.90 & 1.00 & 1.10 & 1.15 & 1.20 \\
\hline Top temperature, ${ }^{\circ} \mathrm{C}$ & 60 & 61 & 63 & 64 & 66 \\
\hline Bottom temperature, ${ }^{\circ} \mathrm{C}$ & 128 & 127 & 128 & 129 & 128 \\
\hline Data of the analytical control: & \multicolumn{7}{|l}{} \\
\hline $\begin{array}{l}\text { Content of } \mathrm{C}_{5} \mathrm{H}_{12} \text { in the } \\
\text { propane- butane fraction, \% }\end{array}$ & 2.16 & 1.11 & 0.37 & 0.10 & 0.05 \\
\hline $\begin{array}{l}\text { Content of } \mathrm{C}_{3} \mathrm{H}_{8}+\mathrm{C}_{4} \mathrm{H}_{10} \text { in } \\
\text { the casinghead gasoline, \% }\end{array}$ & 0.89 & 0.72 & 0.33 & 0.15 & 0.09 \\
\hline
\end{tabular}

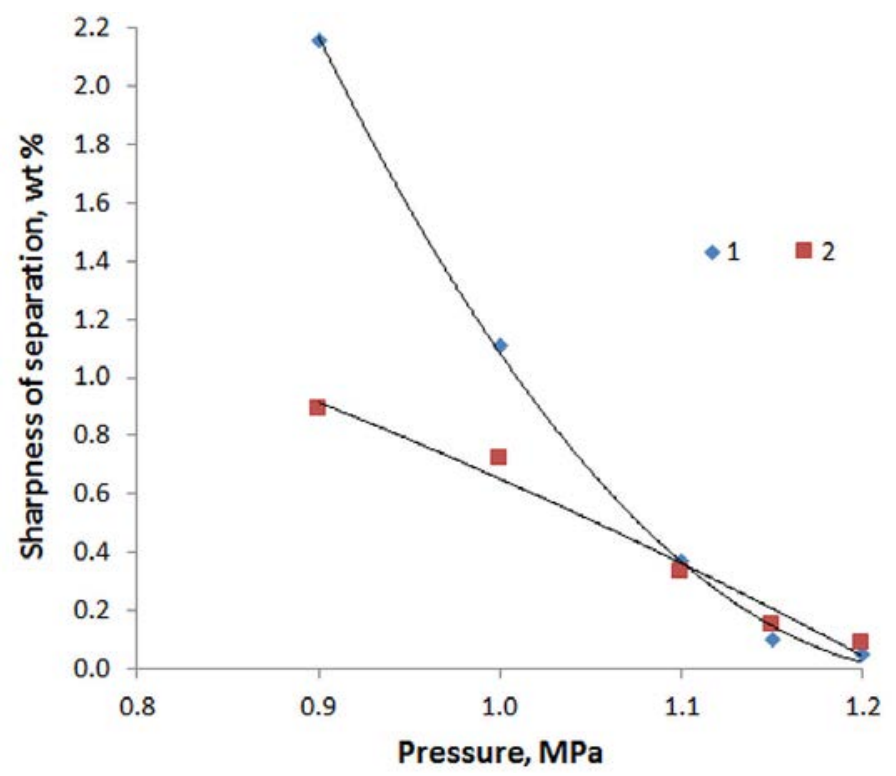

Figure 1: Influence of pressure in the butane column of the sharpness of separation: 1 content of $\mathrm{C} 5 \mathrm{H} 12$ in the propane-butane fraction, wt.\%; 2 - content of $\mathrm{C} 3 \mathrm{H} 8+\mathrm{C} 4 \mathrm{H} 10$ in casinghead gasoline, wt.\%.

regulations. All stabilization columns had the same type of contact devices - valve plates; their number for the columns under the study was in a range of $27-40$ plates. The sharpness of separation in the stabilization columns, presented in Table 2 along with changes in the indicators of the technological regime and the number of contact devices, remained virtually unchanged.

Table 3 and Fig. 2 show the results of the study on the effect of pressure on the stabilization of gasoline containing 6.52 wt.\% of $\mathrm{C}_{4} \mathrm{H}_{10}$ and 18.8 wt.\% of $\mathrm{C}_{5} \mathrm{H}_{12}$. Experimental-industrial run was carried out at the Surgut condensate stabilization plant (CSP). 
Table 2: Statistical data of several petroleum refineries on the operating of the stabilization columns of straight-run gasoline fractions with boiling range IBP $-180^{\circ} \mathrm{C}$.

\begin{tabular}{|c|c|c|c|}
\hline \multirow[b]{2}{*}{ Designation of indicators } & \multicolumn{3}{|c|}{ Value of indicators } \\
\hline & $\begin{array}{c}\text { Novoshakhtinsk } \\
\text { refinery }\end{array}$ & $\begin{array}{c}\text { LLC «Yenisei», } \\
\text { Usinsk }\end{array}$ & $\begin{array}{c}\text { Nizhnekamsk } \\
\text { refinery }\end{array}$ \\
\hline \multicolumn{4}{|l|}{ Contact devices: } \\
\hline Type & \multicolumn{3}{|c|}{ Valvate } \\
\hline Number, units & 31 & 27 & 40 \\
\hline Distance, $\mathrm{mm}$ & 700 & 700 & 700 \\
\hline \multicolumn{4}{|l|}{ Pressure value, MPa } \\
\hline Operating & 0.80 & 0.80 & 0.80 \\
\hline Permissible & 1.40 & 1.80 & 1.40 \\
\hline \multicolumn{4}{|l|}{ Temperature value, ${ }^{\circ} \mathrm{C}$} \\
\hline Top & 68 & 67 & 67 \\
\hline Bottom & 187 & 190 & 188 \\
\hline Feedstock input & 170 & 168 & 174 \\
\hline Reflux ratio & 9.0 & 8.5 & 8.7 \\
\hline $\begin{array}{l}\text { Content of } \mathrm{C}_{4} \mathrm{H}_{10} \text { in the fraction } \\
\text { stabilized IBP- } 180^{\circ} \mathrm{C} \text {, wt. } \%\end{array}$ & 1.63 & 1.89 & 1.47 \\
\hline $\begin{array}{l}\text { Content of } \mathrm{C}_{5} \mathrm{H}_{12} \text { in the head } \\
\text { fraction of stabilization, wt. } \%\end{array}$ & 2.38 & 2.24 & 2.17 \\
\hline
\end{tabular}

The data obtained demonstrate the possibility of significant improvement in the efficiency of the stabilization columns of straight-run gasoline at elevated pressure, which results in increasing the sharpness of rectification. Thus, when increasing the pressure from 0.8 to 1.4 $\mathrm{MPa}$ (which corresponds to the allowable pressure for the stabilization columns of Novoshakhtinsk and Nizhnekamsk refineries, Table 2) in the experimental-industrial run undertaken, both $\mathrm{C}_{4} \mathrm{H}_{10}$ content in stable gasoline and $\mathrm{C}_{5} \mathrm{H}_{12}$ content in the head fraction of stabilization at different capacities was reduced by $57-82 \%$ and $53-88 \%$, respectively. When increasing the pressure from 0.8 to $1.8 \mathrm{MPa}$ (corresponding to the allowable pressure for the stabilization column of oil and gas producing enterprise LLC «Yenisei», Usinsk, Table 2), $\mathrm{C}_{4} \mathrm{H}_{10}$ content in stable gasoline and $\mathrm{C}_{5} \mathrm{H}_{12}$ content in the head fraction of stabilization at different capacities was reduced by $86-96 \%$ and $85-97 \%$, respectively.

Table 4 and Fig. 3 present the results of study on the effect of pressure of the process of stabilization of deethanized condensate with the density value of $677.9 \mathrm{~kg} / \mathrm{m}^{3}$ (at $20^{\circ} \mathrm{C}$ ). Composition of feedstock, wt.\%: $\mathrm{C}_{1}+\mathrm{C}_{2}-0.5 ; \mathrm{C}_{3}-12.09 ; \mathrm{i}-\mathrm{C}_{4}-7.14 ; \mathrm{n}-\mathrm{C}_{4}-10.6 ; \mathrm{i}-\mathrm{C}_{5}-5.47 ; \mathrm{n}-$ $\mathrm{C}_{5}-5.29$. Experimental-industrial run was carried out at the Surgut CSP. 
Table 3: Operating mode of the gasoline stabilization column of the Surgut CSP at the constant output and variable pressure.

\begin{tabular}{|c|c|c|c|c|c|c|}
\hline \multirow{2}{*}{ Designation of indicators } & \multicolumn{6}{|c|}{$\begin{array}{l}\text { Value of indicators at the given pressure in the } \\
\text { column, } \mathrm{MPa}\end{array}$} \\
\hline & 0.80 & 1.00 & 1.20 & 1.40 & 1.60 & 1.80 \\
\hline \multicolumn{7}{|c|}{ Feed capacity of the stabilization column of $70 \mathrm{~m}^{3} / \mathrm{h}$} \\
\hline Top temperature, ${ }^{\circ} \mathrm{C}$ & 67 & 68 & 68 & 67 & 69 & 70 \\
\hline Bottom temperature, ${ }^{\circ} \mathrm{C}$ & 190 & 190 & 192 & $190 \mathrm{M}$ & 192 & 191 \\
\hline Reflux ratio & 8.5 & 8.5 & 8.5 & 8.5 & 8.5 & 8.5 \\
\hline $\begin{array}{l}\text { Content of } \mathrm{C}_{4} \mathrm{H}_{10} \text { in stable } \\
\text { gasoline, wt. } \%\end{array}$ & 1.89 & 1.23 & 0.71 & 0.34 & 0.16 & 0.07 \\
\hline $\begin{array}{l}\text { Content of } \mathrm{C}_{5} \mathrm{H}_{12} \text { in the head } \\
\text { fraction of stabilization, wt.\% }\end{array}$ & 2.24 & 1.47 & 0.78 & 0.26 & 0.19 & 0.06 \\
\hline \multicolumn{7}{|c|}{ Feed capacity of the stabilization column of $100 \mathrm{~m}^{3} / \mathrm{h}$} \\
\hline Top temperature, ${ }^{\circ} \mathrm{C}$ & 67 & 69 & 68 & 70 & 70 & 71 \\
\hline Bottom temperature, ${ }^{\circ} \mathrm{C}$ & 191 & 190 & 192 & 191 & 193 & 192 \\
\hline Reflux ratio & 8.5 & 8.5 & 8.5 & 8.5 & 8.5 & 8.5 \\
\hline $\begin{array}{l}\text { Content of } \mathrm{C}_{4} \mathrm{H}_{10} \text { in stable } \\
\text { gasoline, wt. } \%\end{array}$ & 2.91 & 2.43 & 1.66 & 1.07 & 0.62 & 0.27 \\
\hline $\begin{array}{l}\text { Content of } \mathrm{C}_{5} \mathrm{H}_{12} \text { in the head } \\
\text { fraction of stabilization, wt.\% }\end{array}$ & 4.06 & 3.36 & 2.19 & 1.02 & 0.67 & 0.31 \\
\hline \multicolumn{7}{|c|}{ Feed capacity of the stabilization column of $140 \mathrm{~m}^{3} / \mathrm{h}$} \\
\hline Top temperature, ${ }^{\circ} \mathrm{C}$ & 69 & 72 & 70 & 71 & 73 & 72 \\
\hline Bottom temperature, ${ }^{\circ} \mathrm{C}$ & 193 & 195 & 196 & 194 & 196 & 195 \\
\hline Reflux ratio & 8.5 & 8.5 & 8.5 & 8.5 & 8.5 & 8.5 \\
\hline $\begin{array}{l}\text { Content of } \mathrm{C}_{4} \mathrm{H}_{10} \text { in stable } \\
\text { gasoline, wt. } \%\end{array}$ & 4.99 & 4.47 & 3.31 & 2.13 & 1.39 & 0.69 \\
\hline $\begin{array}{l}\text { Content of } \mathrm{C}_{5} \mathrm{H}_{12} \text { in the head } \\
\text { fraction of stabilization, wt.\% }\end{array}$ & 7.14 & 6.20 & 5.01 & 3.37 & 2.08 & 1.10 \\
\hline
\end{tabular}

When increasing the pressure from 0.6 to $1.6 \mathrm{MPa}$ in the experimental-industrial run undertaken, $\mathrm{C}_{4} \mathrm{H}_{10}$ content in stable condensate and $\mathrm{C}_{5} \mathrm{H}_{12}$ content in the head fraction of stabilization at different capacity was reduced by $90-97 \%$ and $92-96 \%$, respectively.

\section{CONCLUSIONS}

It was found that increasing the pressure results in increasing the sharpness of separation of butanes from pentanes, which positively affects both the balance of the process and the quality of the products obtained. Thus, in the stabilization columns, increasing the pressure 
Table 4: Operating mode of the stabilization column of deethanized condensate at the constant throughput and variable pressure.

\begin{tabular}{|c|c|c|c|c|c|c|}
\hline \multirow{2}{*}{ Designation of indicators } & \multicolumn{6}{|c|}{$\begin{array}{l}\text { Value of indicators at the given pressure in the column, } \\
\mathrm{MPa}\end{array}$} \\
\hline & 0.60 & 0.80 & 1.00 & 1.20 & 1.40 & 1.60 \\
\hline \multicolumn{7}{|c|}{ Feed capacity of the stabilization column of $200 \mathrm{~m}^{3} / \mathrm{h}$} \\
\hline Top temperature, ${ }^{\circ} \mathrm{C}$ & 74 & 74 & 76 & 75 & 77 & 76 \\
\hline Bottom temperature, ${ }^{\circ} \mathrm{C}$ & 197 & 197 & 200 & 198 & 196 & 199 \\
\hline Reflux ratio & 10.0 & 10.0 & 10.0 & 10.0 & 10.0 & 10.0 \\
\hline $\begin{array}{l}\text { Content of } \mathrm{C}_{4} \mathrm{H}_{10} \text { in stable } \\
\text { condensate, wt.\% }\end{array}$ & 1.40 & 0.84 & 0.43 & 0.16 & 0.06 & 0.04 \\
\hline $\begin{array}{l}\text { Content of } \mathrm{C}_{5} \mathrm{H}_{12} \text { in the head } \\
\text { fraction of stabilization, wt.\% }\end{array}$ & 3.08 & 1.87 & 1.12 & 0.54 & 0.31 & 0.21 \\
\hline \multicolumn{7}{|c|}{ Feed capacity of the stabilization column of $260 \mathrm{~m}^{3} / \mathrm{h}$} \\
\hline Top temperature, ${ }^{\circ} \mathrm{C}$ & 76 & 75 & 77 & 76 & 78 & 79 \\
\hline Bottom temperature, ${ }^{\circ} \mathrm{C}$ & 200 & 197 & 198 & 199 & 200 & 198 \\
\hline Reflux ratio & 10.0 & 10.0 & 10.0 & 10.0 & 10.0 & 10.0 \\
\hline $\begin{array}{l}\text { Content of } \mathrm{C}_{4} \mathrm{H}_{10} \text { in stable } \\
\text { condensate, wt.\% }\end{array}$ & 2.19 & 1.22 & 0.66 & 0.39 & 0.22 & 0.13 \\
\hline $\begin{array}{l}\text { Content of } \mathrm{C}_{5} \mathrm{H}_{12} \text { in the head } \\
\text { fraction of stabilization, wt.\% }\end{array}$ & 6.45 & 4.06 & 2.81 & 1.22 & 0.53 & 0.26 \\
\hline \multicolumn{7}{|c|}{ Feed capacity of the stabilization column of $300 \mathrm{~m}^{3} / \mathrm{h}$} \\
\hline Top temperature, ${ }^{\circ} \mathrm{C}$ & 75 & 77 & 78 & 76 & 79 & 80 \\
\hline Bottom temperature, ${ }^{\circ} \mathrm{C}$ & 200 & 197 & 198 & 196 & 202 & 201 \\
\hline Reflux ratio & 10.0 & 10.0 & 10.0 & 10.0 & 10.0 & 10.0 \\
\hline $\begin{array}{l}\text { Content of } \mathrm{C}_{4} \mathrm{H}_{10} \text { in stable } \\
\text { condensate, wt. } \%\end{array}$ & 3.01 & 2.02 & 1.38 & 0.79 & 0.51 & 0.28 \\
\hline $\begin{array}{l}\text { Content of } \mathrm{C}_{5} \mathrm{H}_{12} \text { in the head } \\
\text { fraction of stabilization, wt.\% }\end{array}$ & 9.32 & 6.99 & 4.72 & 3.30 & 1.51 & 0.72 \\
\hline
\end{tabular}

within the limits acceptable for these columns can increase the efficiency of their operation. Earlier, an approach for improving the efficiency of the rectification process using surfactants was proposed [15]. It is of interest to investigate the joint application of surfactants and increasing the pressure within the acceptable limits to improve the efficiency of rectification processes. 


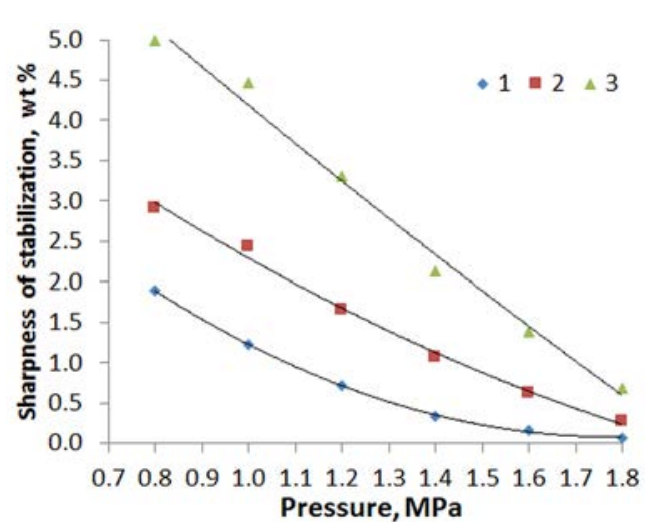

(a)

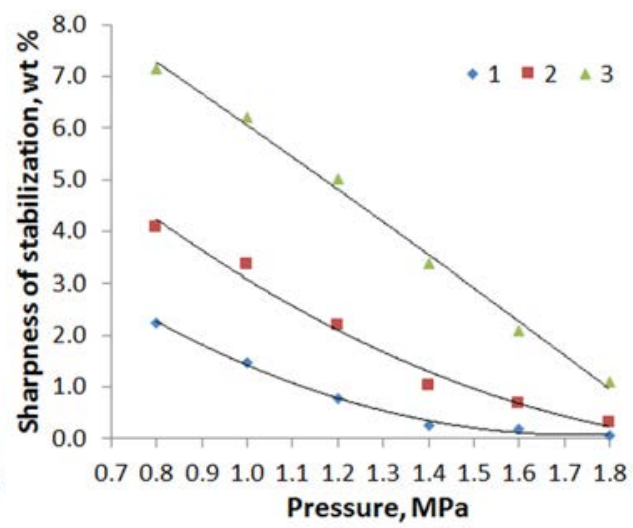

(b)

Figure 2: Effect of pressure in the column on the sharpness of stabilization of gasoline. (a) Content of C4H10 in stable gasoline, wt.\%; (b) Content of C5H12 in the head fraction of stabilization wt.\%. Feed capacity of the stabilization column, $\mathrm{m}^{3} / \mathrm{h}$ : $1-70,2-100,3-140$.

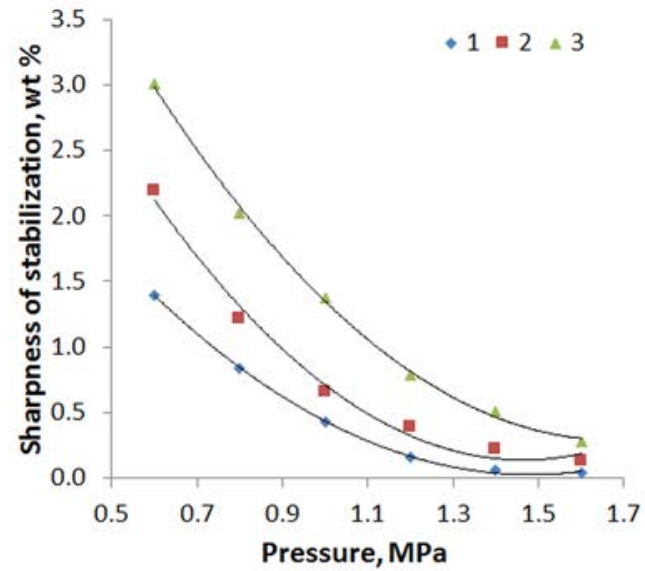

(a)

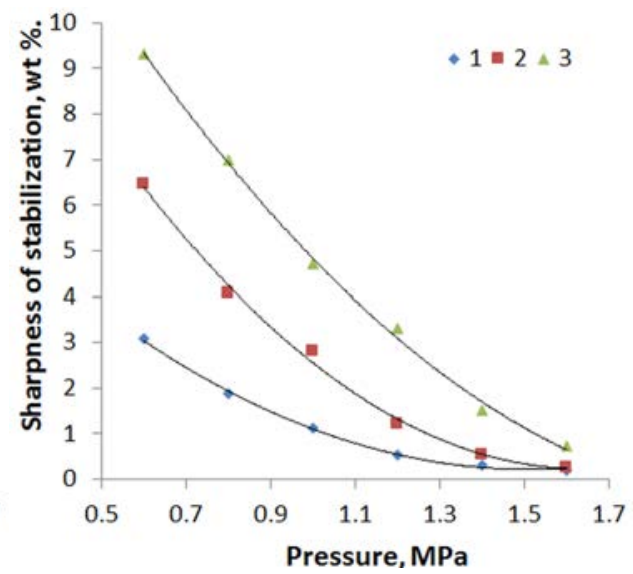

(b)

Figure 3: Effect of pressure in the column on the sharpness of stabilization of deethanized condensate. (a) Content of $\mathrm{C} 4 \mathrm{H} 10$ in stable condensate, wt.\%; (b) Content of $\mathrm{C} 5 \mathrm{H} 12$ in the head fraction of stabilization wt.\%. Feed capacity of the stabilization column, $\mathrm{m}^{3} / \mathrm{h}$ : 1-200, 2-260, 3-300.

\section{ACKNOWLEDGEMENT}

This research was supported by Act 211 Government of the Russian Federation, contract № 02.A03.21.0006. 


\section{REFERENCES}

[1] Manovyan, A.K., Technology of Primary Processing of Oil and Natural Gas: a Textbook for Universities, 2nd ed., Khimiya: Moscow, 2001.

[2] Scoblo, A.I., Molokanov, Yu.K., Vladimirov, A.I. \& Shchelkunov, V.A., Processes and Apparatuses of Oil and Gas Refining and Petrochemistry: A Textbook for Universities, 3rd ed. revised and enlarged, LLC "Nedra-Business Center": Moscow, pp. 101-183, 2000.

[3] Nag, A., Distillation \& Hydrocarbon Processing Practices, PennWell Corporation: Tulsa, pp. 1-270, 2016.

[4] Pinto, F.S., Zemp, R., Jobson, M. \& Smith, R., Thermodynamic optimization of distillation columns. Chemical Engineering Science, 66, pp. 2920-2934, 2011.

[5] Aleksandrov, I.A., Distillation and Rectification in Oil Refining, Khimiya: Moscow, 1981.

[6] Halvorsen, I. J. \& Skogestad, S., Energy efficient distillation. Journal of Natural Gas Science and Engineering, 3, pp. 571-580, 2011.

[7] Long, N.V.D. \& Lee, M., Review of retrofitting distillation columns using thermally coupled distillation sequences and dividing wall columns to improve energy efficiency. Journal of Chemical Engineering of Japan, 47(2), pp. 87-108, 2014. DOI: $10.1252 /$ jcej.13we067.

[8] Kister, H.Z. \& Doig, I.D., Studies of the effect of pressure on distillation heat requirements. Chemical Engineering Communications, 11(1-3), pp. 1-12, 1981. DOI: 10.1080/00986448108910983.

[9] Jobson, M., Gorak, A. \& Sorensen, E. (ed), Energy considerations in distillation. Distillation: Fundamentals and Principles, Distillation, vol. 1, Elsevier Academic Press: London, pp. 225-270, 2014.

[10] Liu, Z.-Y. \& Jobson, M., The effect of operating pressure on distillation column throughput. Computers \& Chemical Engineering, 23(Supplement 1), pp. S831-S834, 1999. DOI: 10.1016/s0098-1354(99)80204-x.

[11] Castillo, F.J.L. \& Dhole, V.R., Pressure analysis of the ethylene cold-end process. Computers \& Chemical Engineering, 19, pp. 89-94, 1995. DOI: 10.1016/00981354(95)87020-2.

[12] Rogalev, M.S. \& Magaril, R.Z., Increasing and evaluation of the rectification tower trays efficiency, Izvestia Vyssih Ucebnyh Zavedenij. Neft i Gaz, 6, pp. 92-97, 2011.

[13] Rogalev, M.S. \& Magaril, R.Z., The influence of rectification sharpness on the quality of motor fuels. WIT Transactions on Ecology and the Environment, vol. 190, WIT Press: Southampton and Boston, pp. 833-843, 2014.

[14] Ermolin, D.B., Rogalev, M.S., Magaril, R.Z. \& Trushkova, L.B., Influence of pressure on rectification sharpness in deethanization towers. Izvestia Vyssih Ucebnyh Zavedenij. Neft i Gaz, 5, pp. 107-113, 2014.

[15] Ali, A.A., Magaril, R.Z., Rogalev, M.S. \& Magaril E.R., Acceleration of boiling in the desired conditions. Application of its effect in refinery and petrochemical industries. WIT Transactions on Ecology and the Environment, vol. 186, WIT Press: Southampton and Boston, pp. 535-543, 2014. 